\title{
Investors' trading behaviour and stock market volatility during crisis periods: A dual long-memory model for the Korean Stock Exchange
}

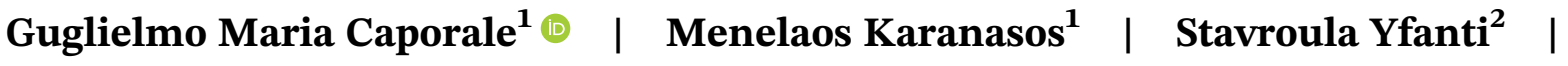 \\ Aris Kartsaklas ${ }^{1}$
}

${ }^{1}$ Department of Economics and Finance, Brunel University, London, UK

${ }^{2}$ School of Business and Economics, Loughborough University, UK

\section{Correspondence}

Guglielmo Maria Caporale, Department of Economics and Finance, Brunel University, Uxbridge, England.

Email: guglielmo-maria.caporale@brunel. ac.uk

\begin{abstract}
This study examines the impact of investors' buy and sell trades on Korean stock market volatility across two crisis events, the Asian crisis of 1997 and the 2008 global financial crash. We investigate the trading behaviour of domestic vs. foreign and institutional vs. individual investors. Our results suggest that the buy and sell trades have an asymmetric effect on volatility that depends on the type of investor trading and on the phase of the business cycle. Buy orders appear to be more informative than sell orders since they mostly lower volatility in the pre-crisis periods, while sell and post-crisis buy trades affect volatility positively regardless of who trades (institutional or individual investors) and on what information (member, non-member). Most importantly, decomposing total buy and sell trades into trader-type categories reveals that some institutional investors are more informed traders that stabilize the market compared to individuals that always increase volatility. Foreign investors reduce volatility with their purchases and total trading activity in the whole Asian crisis sample, but only in the pre-crisis period before the recent global financial turmoil.
\end{abstract}

\section{K E Y W O R D S}

financial crisis, foreign investors, individual investors, institutional investors, long memory, range-based volatility, structural change, trading volume

\section{1 | INTRODUCTION}

The relationship between trading volumes and volatility has been analysed in numerous studies in the areas of behavioural finance and financial econometrics; these have shown that investors' trading activity affects stock market volatility considerably, which has important implications for financial regulators. The empirical evidence on emerging markets has focused particularly on foreign investors' behaviour. By contrast, following Karanasos and Kartsaklas (2009), the present paper investigates the volume-volatility link in the Korean Stock Exchange for different investor categories (domestic vs. foreign, institutional vs. individual investors) and orders (buy vs. sell trades), during the 1997 Asian turmoil and the 2008 global financial crisis (GFC).

To the best of our knowledge, this is the first attempt to compare the two crises in terms of the volume- 
volatility link across different investor types. Our empirical analysis contributes to the behavioural finance literature and in particular the market microstructure research about the impact of buy and sell trades on stock market volatility during two of the main financial crises in the last two decades. Karanasos and Kartsaklas (2009) focused on the domestic vs. foreign investors' trading activity around the Asian financial crisis. We extend their work and examine the effect of domestic vs. foreign and institutional vs. individual investors' buy, sell and total trading decisions on range-based volatility measures. Specifically, our unique dataset makes it possible to investigate the trading behaviour of seven different types of domestic institutional investors, namely securities companies, insurance companies, mutual funds, investment banks, commercial banks, savings banks and other companies.

The two main parameters driving the degree of persistence in volatility and its uncertainty are estimated using a bivariate GARCH model that is Fractionally Integrated (FI) in both the autoregressive (AR) mean and variance specifications. We refer to this model as the ARFI-FIG$\mathrm{ARCH}$. It provides a general and flexible framework to study persistent processes such as volume and volatility.

Overall, buy orders appear to be more informative and value-driven, while sell orders are less informative and possibly more market phase driven since they affect stock market volatility positively. During both crises domestic individual (as well as non-member institutional) investors appear to have destabilized the market, while the member institutional ones exhibit less of an information advantage in the 2008 crisis compared to the 1997 Asian financial crisis (AFC).

In the two post-crisis periods trading activity destabilizes the market. In the two pre-crisis periods, inside the institutional non-members group, we find that active investors lower volatility during the Asian financial turmoil, while in the case of the recent global crash the stabilizers are the passive ones, confirming the hypothesis that passive institutional traders use limit orders and engage in contrarian trades. Interestingly, it seems that active investors have engaged in herding and positive feedback strategies during the GFC, when their total trading has affected volatility positively. Finally, the whole trading activity, as well as the foreign one, in the two pre-crisis periods has stabilized the market, whereas in the case of the GFC its impact on volatility has become positive after the crisis.

The remainder of the paper is structured as follows. Section 2 reviews the existing empirical evidence on the trading behaviour of institutional, individual and foreign investors and allows us to develop our theoretical hypotheses on the volume-volatility link. Section 3 describes the data, while Section 4 outlines the econometric model and estimation procedure. Section 5 presents the empirical results for different investor categories around the AFC. In Section 6, we apply the dual longmemory model of the volume-volatility link to the GFC of 2008. Section 7 offers some concluding remarks.

\section{2 | THEORETICAL BACKGROUND}

\section{1 | Hypotheses}

In this Section we develop two hypotheses for the volume-volatility link. The first concerns the investment style (Hypothesis 1, H1) and the second is based on the investors' information advantage (Hypothesis 2, H2).

First, we look into the effect of active (insurance companies, mutual funds, and investment banks) vs. passive (commercial banks, savings banks and other companies) institutional non-member investors based on a finer partition of trading volume data into the six different nonmember categories. In line with the literature reviewed below, we assume that traders who use market orders to assure rapid execution (at the cost of large price impacts) and engage in herding and positive feedback trades (based on short-lived information) will exacerbate shortrun volatility (H1a). By contrast, traders who use limit orders and pursue contrarian trades (based on long-term information) will reduce short-run volatility $(H 1 b)$. Koutmos and Saidi (2001) investigate the positive feedback trading practice leading to excess emerging markets volatility (H1a). Avramov et al. (2006) decompose sell trades into contrarian and herding ones and they find that herding trades increase volatility, while contrarian trades have a stabilizing impact $(H 1 b)$. Although for some institutions the buy-sell decision has no association with prior excess returns, for others there is a significant relation between trades and past excess returns. However, the overall effect of these strategies may be offsetting, because some traders engage in more contrarian strategies, while others follow market trends. In general, we would expect active traders to use market orders and engage in herding and positive feedback trades, whereas passive traders should use limit orders and pursue more contrarian trades.

Secondly, we expect uninformed trading to exacerbate stock market volatility $(\mathrm{H} 2 \mathrm{a})$, while informed trading will be associated with less volatility in the Korean Stock Exchange (H2b). For investors with no access to order flow data (less informed) we expect a wider dispersion of beliefs since they cannot differentiate short-term liquidity 
demand from changes in overall fundamental supply and demand. As a result, less informed traders, here proxied by individual and foreign investors, are expected to buy and sell within a wider range of prices around the fair value of the asset. On the other hand, if investors have an information advantage due to access to market data, they are likely to form homogeneous expectations about market movements and the fundamental characteristics of an asset. If this is the case informed traders, proxied by member institutional investors in this study, are expected to buy and sell within a small range of prices around the fair value of the asset.

In this paper, we associate the trading of institutional member and individual (and foreign) investors with those of informed and uninformed traders, respectively. We do so, not by means of serial correlation tests (Campbell et al., 1993, Easley et al., 1997) or conditioning on past price changes (Avramov et al., 2006), but by taking into account the distinction made by the Korean Stock Exchange between institutional (member and non-member) and individual investors as in Daigler and Wiley (1999). Here, the latter are treated as uninformed (or less informed), because their orders are channelled through members' trading pits. Moreover, individual investors are significantly affected by psychological biases, which lead to increased levels of trading, systematic behaviour and high trading costs. Institutional member investors are treated as informed because members' direct access to the trading system provides them with short-term information such as trading activity at specific prices, and price trends. They also have specific information about their own customers' supply and demand in the cash and futures markets.

Institutional or large block trades are more informative than small trades and are more likely to cause permanent price changes (Easley and O'Hara, 1987, Easley et al., 1997). Daigler and Wiley (1999) find that the positive volume-volatility relation is driven by the (uninformed) general public (H2a), whereas the activity of informed traders such as clearing members and floor traders is often inversely related to volatility ( H2b). Kelley and Tetlock (2013) show that overconfidence (not hedging) explains nearly all uninformed trading. Abbes (2013) provides further evidence of the destabilizing effect of trading volume on volatility, which can be attributed to investors' overconfidence bias in both developed and emerging stock markets. In the multicountry context, several studies on the Asian stock markets also find a positive relationship between aggregate trading volume and volatility. For example, Pisedtasalasai and Gunasekarage (2007) and Chuang et al. (2012) report a positive volume-volatility link for the Philippines, Singapore, Hong Kong, Korea, China, Indonesia and Thailand. Finally, Girard and Biswas (2007) find that volatility persistence decreases when the trading volume is decomposed into its expected and unexpected components in all markets under investigation, including most Asian developed and emerging ones.

\section{2 | Trading behaviour}

\subsection{1 | Sentiment}

Increased volatility in financial markets could also reflect sentiment-induced mispricing or time-varying risk (or risk aversion that causes time variation in expected stock returns). Baker and Wurgler $(2006,2007)$ argue that sentiment traders shift from safe to speculative securities when sentiment increases, and from speculative to safe securities when sentiment declines, and that these sentiment-induced demand shocks drive mispricing in financial markets. Moreover, market-wide sentiment should have a greater effect on securities that are hard to arbitrage and difficult to value. Consistently with this prediction, they find that when sentiment is low, subsequent returns are relatively high for small, young, high volatility, profitable, non-dividend-paying, extreme growth and distressed stocks. When sentiment is high, on the other hand, these categories of stocks have relatively low subsequent returns. ${ }^{1}$

DeVault et al. (2019) find that commonly used measures of investor sentiment capture the demand shocks of institutional, rather than individual, investors. In other words, the traders driving the sentiment-induced mispricing are institutional, rather than individual, investors (on aggregate). In particular, the level of institutional investors' speculative stock holdings, relative to that of their holdings of safe stocks, increases when sentiment is higher. More importantly, differences in investment styles (risk management and reputation concerns, momentum and herding trading) across types of institutional investors help explain institutional sentiment trading. For example, institutions such as banks, insurance companies and pension funds tend to avoid holding and trading risky stocks, which implies that they do not contribute much to aggregate institutional sentiment trading. By contrast, institutions such as mutual funds, hedge funds and independent advisors are not only more willing to hold such stocks but are also more sensitive to lag performance, which suggests that risk management and reputational concerns could influence their sentiment trading.

\subsection{2 $\quad$ Institutional investors}

Much of the empirical research in finance views individuals and institutions differently. In particular, while 
institutions are viewed as informed investors, individuals are believed to be affected by psycho- logical biases and often characterized as noise traders (Black, 1986). Institutional investors consistently dedicate more resources to acquiring and analysing information, while their trading motives determine their investment styles (active or passive) and order placement strategies (market or limit orders) when they buy or sell stocks in the securities markets. Actively managed funds buy and sell stocks on the basis of valuation beliefs but, for some institutions, trades are affected by pre-determined investment objectives (index tracking, value, growth), liquidity needs and taxmanagement purposes (Alexander et al., 2007). If active institutional traders use market orders and engage in herding and positive feedback trades, on the basis of short-lived information, this is likely to increase shortrun volatility. De Long et al. (1990) argue that in the presence of positive feedback traders, rational speculation (or trading by institutional investors) can be destabilizing (H1a). On the other hand, passive institutional traders who use limit orders and engage in more contrarian or value-motivated trades are likely to reduce volatility in the short run $(H 1 b)$. Lakonishok et al. (1992) use data on the holdings of tax-exempt (predominantly pension) funds to evaluate the potential effect of their trading on stock prices. Their evidence suggests that institutional herding moves prices, but not necessarily in a destabilizing way. For example, if all investors react to the same fundamental information prices will adjust faster to new fundamentals.

For the Chinese market, institutional trades are considered more informative and overall reduce market volatility (Li and Wang, 2010). Cai et al. (2010), using a unique dataset of the Chinese stock market, document how a higher proportion of trades initiated by institutional investors can be considered as informed $(\mathrm{H} 2 \mathrm{~b})$ compared to trades initiated by individuals $(\mathrm{H} 2 a)$. This result is consistent with the argument that institutional investors are better informed and therefore can earn bigger profits than individuals. ${ }^{2}$ By contrast, exploring the incentives of institutional trading, Basak and Pavlova (2013) develop an asset-pricing model with institutional investors' incentives to overperform their benchmarks and find that their trading increases market volatility. $^{3}$

\subsection{3 | Individual investors}

Barber et al. (2009) show that the aggregate portfolio of individuals performs poorly and almost all individual trading losses can be traced to their aggressive orders.
Behavioural biases such as overconfidence can possibly explain why retail investors trade so much and self-manage their portfolios (see Daniel et al., 1998; Odean, 1998; Gervais and Odean, 2001; Kelley and Tetlock, 2013). Barber et al. (2009a) construct portfolios that mimic the purchases and sales of each investor group in order to analyse who gains and losses from trade. Individual investors incur substantial losses, while institutional ones (corporations, dealers, foreigners, and mutual funds) gain from trade. Moreover, individual investors tend to hold on to losing common stock positions and sell their winners (the "disposition effect"), buy stocks that catch their attention (or which they are familiar with), under-diversify their stock portfolios and engage in naïve reinforcement learning by repeating past behaviours that coincided with pleasure, while avoiding past behaviours that generated pain (Barber and Odean, 2008, 2011). As a result, the buy and sell decisions of individual traders are likely to exacerbate volatility, unless the liquidity provided by individual traders is matched by increased levels of informed trading by institutional investors. Herding, feedback and/or uninformed trading have the potential to explain destabilizing stock prices or excess volatility (H1a, H2a). However, they have also been used to explain momentum and reversals in stock prices depending on who trades and on what type of information. Others also argue that individual traders overinvest in stocks because they are familiar with them (or love gambling), leading to under-diversification (Goetzmann and Kumar, 2008) and average or even below-par returns (Anderson, 2013). Barber et al. (2009b) provide evidence that the trading of individuals is highly correlated and persistent. This systematic trading of individual investors is not primarily driven by passive reactions to institutional herding, by systematic changes in risk aversion or by taxes. Psychological biases contribute to the correlated trading of individuals, which leads investors to systematically buy stocks with strong recent performance, to refrain from selling stocks held at a loss, and to be net buyers of stocks with unusually high trading volume. Foucault et al. (2011) provide evidence based on French data that individual investors as noise traders exacerbate stock returns volatility, in line with $(H 2 a)$. By contrast, the study by Che (2018) concludes that individuals reduce volatility in Norway, where they are shown to be contrarian traders $(H 1 b)$.

\subsection{4 | Foreign investors}

Brennan and Cao (1997) present a theoretical model and empirical evidence that supports the view that foreign 
investors in the US have to pursue momentum strategies and achieve inferior performance because they are less informed than domestic investors (H1a, H2a). ${ }^{4}$ Grinblatt and Keloharju (2001) also find that foreign investors, and often professionally managed funds or investment banking houses, pursue momentum strategies and achieve superior performance. Chen et al. (2013) shed further light on the positive relationship of foreign institutional ownership on Chinese equities with stock return volatility. After removing momentum investing's contribution to performance, they find that the momentum-adjusted performance of foreigners is still highly significant ( $\mathrm{H} 2 a$ ). Similarly, Che (2018) finds that foreign trading activity in Norway increases volatility because foreign investors are momentum traders while domestic institutions' trading is mostly associated with lower volatility ( $\mathrm{H} 2 b$ ).

Wang (2007) documents a strong contemporaneous relationship between foreign equity trading and market volatility in Indonesia and Thailand. Trading within foreign and local investor groups is often negatively related to market volatility in Indonesia. This is consistent with the view that within each group, investors are relatively homogeneous in terms of capital endowments and information. In particular, in Thailand foreign net purchases are negatively associated with market volatility, therefore they provided liquidity when local investors were under stress to sell and helped to reduce volatility during the Asian crisis by preventing the local markets from dropping further than they actually did.

Turning next to studies on Korea, Choe et al. (1999) find no evidence that trades by foreign investors had a destabilizing effect on Korea's stock market over the 1996-1997 subsample. In particular, the market adjusted quickly and efficiently to large sales by foreign investors, and these sales were not followed by negative abnormal returns. Jeon and Moffett (2010) show that foreign investors in Korea are involved in herding and positive feedback strategies $(\mathrm{H} 1 \mathrm{a}) .^{5}$ Likewise, Bae et al. (2011) provide evidence that foreign and domestic institutional investors trade like momentum traders (H1a, H2a) while individuals behave like contrarians (H1b). Interestingly, Umutlu and Shackleton (2015) point out that uninformed individuals' trading exerts a positive influence on equities volatility $(H 2 a)$, whereas trading by informed domestic institutional investors reduces volatility $(\mathrm{H} 2 \mathrm{~b})$. They also find that foreign trading mostly drives volatility higher (H2a). According to a more recent study on investor sentiment in the Korean Stock Exchange by Yang et al. (2017), foreign and domestic institutional investors are more informed $(H 2 b)$ than individuals, who are mostly affected by psychological biases and act as noise traders $(\mathrm{H} 2 a)$. Table A3 in the Appendix summarizes the main papers presented in this Section.

\section{3 | DATA AND SUB-PERIODS}

We first investigate the trader-type effect of buy and sell trades on volatility for the KOSPI 200 index from 1995 until 2005. This period seems suitable to capture changes in the trading activity across investors. As the market expands and traders become aware of the market's potential, the impact of different investors' trading on volatility becomes very important. In this study, the trading of individual and foreign investors changed significantly in the aftermath of the AFC. The dataset consists of daily data on high, low, open and closing prices of the KOSPI 200 index of the Korean Stock Exchange from the third of January 1995 to the 26th of October 2005 (2,850 observations). For the same period, daily buy and sell trades by eight different types of domestic investors are also available. Specifically, the Korean Stock Exchange publishes the daily buy and sell value (and volume) traded by eight types of domestic investors. Domestic investors are also split into institutionals and individuals, and institutionals are further divided into members and non-members based on their access to the trading system and its information. Non-member institutional investors consist of insurance companies, mutual funds, investment banks, commercial banks, savings banks and other companies. Finally, daily trading volume data are also available for (non-member) foreign investors of the Korean Stock Exchange. The first part of our empirical analysis focuses on the decade around the AFC. In Section 6, we will use data from the decade around the GFC, in order to investigate the volume-volatility link during the most recent financial turmoil and compare the two crises in terms of the trader-type effects stabilizing or destabilizing the stock market.

The case of Korea is particularly interesting since this country considerably improved its economic performance and attracted much greater capital inflows in the period from 1996 to 2015. In particular, Korean GDP grew by 6.5\% (on average per year) from 1996 to 2005 and by 3.5\% from 2006 to 2015, and net capital flows were positive and averaged almost two billion dollars over the whole period considered. The AFC in 1997 also brought changes to the Korean financial system such as abolishing the foreign ownership ceiling in the stock market, allowing free movement of investment profit, and providing transparent financial reports. Moreover, the Korean Derivatives Market opened in 1996 by introducing the KOSPI200 Index Futures. Since then, it has developed into an 


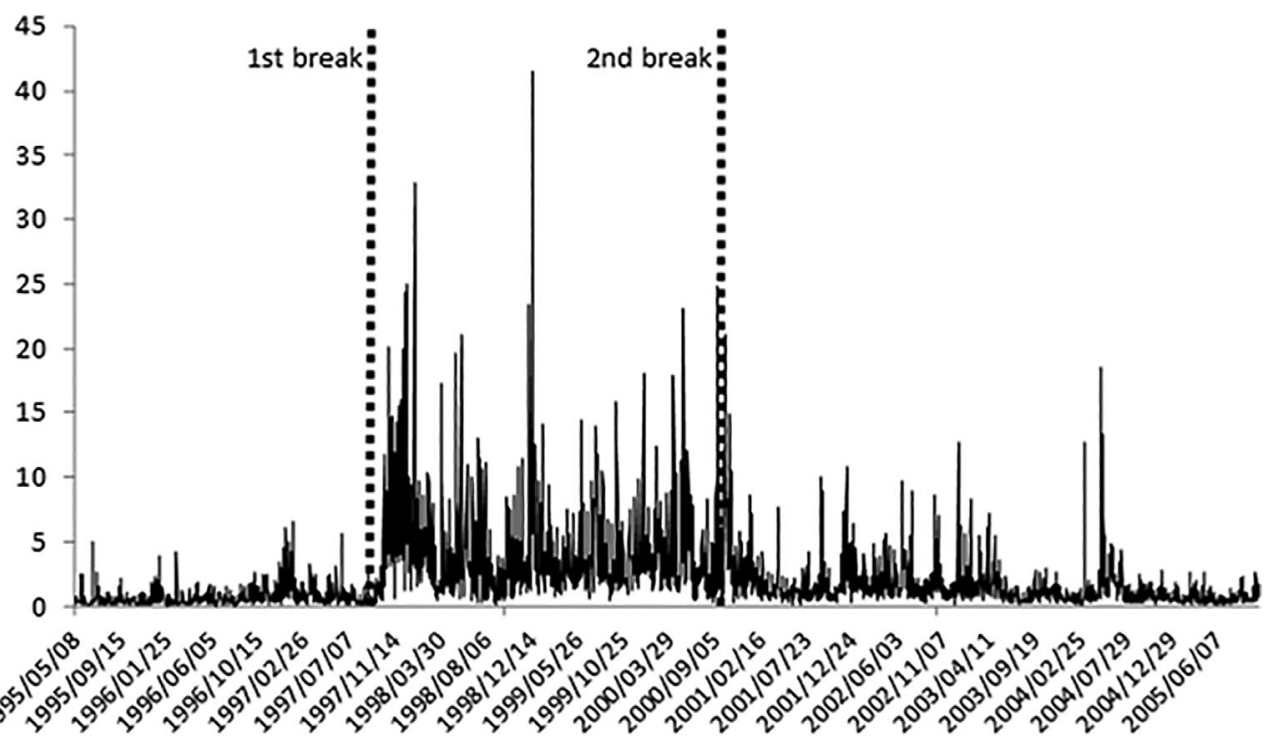

F I G U R E 1 Garman-Klass volatility (AFC period)

international exchange following the establishment of the KOSPI200 Options Market in 1997 and the Korea Treasury Bond Futures and the US Dollar Derivatives Market in 1999. As a result of the rapid growth of options/futures trading in the KOSPI 200, the KRX Derivatives Market overtook the main American, European and other international exchanges to become a world leader in terms of annual trading volume. Specifically, the ratio of KOSPI200 futures cash trading value increased from 0.3 in 1997 to 2.5 in $2015 .^{6}$ These developments together with the two financial crises (the Asian and global financial ones) the Korean Stock Exchange went through raise interesting research questions about their impact on investors' trading behaviour and stock market volatility over the last 20 years.

The Korean stock market has attracted the interest of various researchers (Choe et al., 1999, 2005, Jeon and Moffett, 2010, Umutlu and Shackleton, 2015) due to the unique dataset on the different trader types provided by the Korean Stock Exchange. It is undoubtedly one of the fastest growing stock markets (Bae et al., 2011) after it experienced a radical liberal reform of its financial system by the International Monetary Fund (IMF) following the AFC, which led to dramatic capital inflows from foreign institutional investors (Kim et al., 2005). However, nowadays, South Korea still remains at the frontier between emerging and developed markets. MSCI considers the Korean market in the emerging Asia-Pacific area $^{7}$ while FTSE has classified Korea in the developed markets since $2009^{8}$, which suggests that it shares characteristics of both market categories, developed (MSCI: Hong Kong, Singapore, and Japan) and emerging (MSCI: China, Indonesia, Malaysia, Thailand, etc.) Asian markets. For example, according to the MSCI Accessibility Review, in terms of openness to foreign ownership, South Korea's qualitative level of openness can be compared to similar levels of emerging markets like China, Malaysia and Philippines and the developed markets of Hong Kong and Singapore. Ease of capital flows, market infrastructure and regulation measures are also comparable, exhibiting significant similarities among the Asian stock exchanges. By contrast, institutional framework standards in the emerging Asian markets remain behind the developed economies. Korea faces issues concerning its foreign exchange market liberalization, which represents an obstacle to its being classified as an MSCI developed market. Finally, Yang et al. (2017) focus on Korean investor sentiment, considering the Korean Stock Exchange as a representative emerging market characterized by significant information asymmetry with respect to investor types, high market sentiment, prevalent investor psychology, unique investor participation rates and the various trading purposes of market participants. In conclusion, the KOSPI 200 index is widely regarded as a leading emerging financial market index in East Asia, which is worthy of closer investigation with important implications for the whole region.

\section{1 | Price volatility}

Using data on the daily high, low, opening and closing prices in the index we generate a daily measure of price volatility. We can choose from among several alternative measures, each of which uses different information from the available daily price data. To avoid the microstructure 
F I G U RE 2 Turnover volume (AFC period)

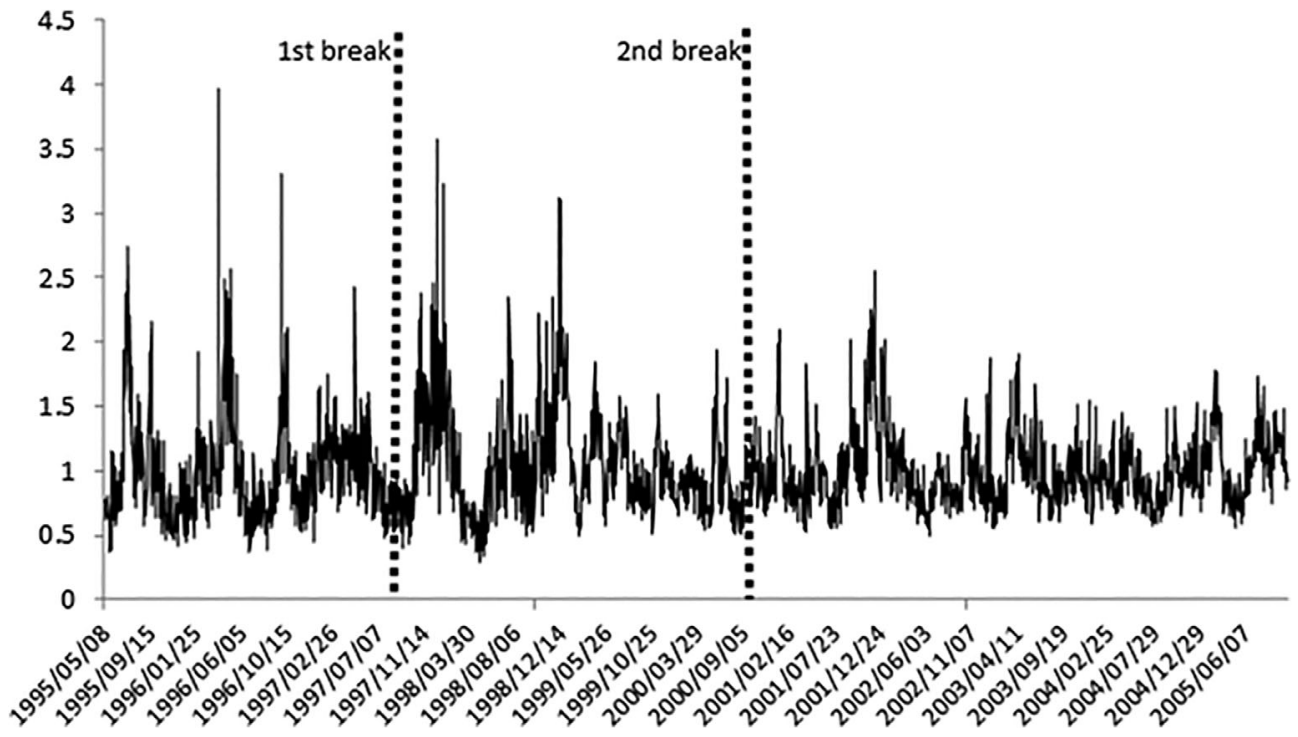

biases introduced by high- frequency data, and on the basis of the conclusion of Chen et al. (2006) that rangebased and high-frequency integrated volatility provide essentially equivalent results, we employ the classic range-based estimator of Garman and Klass (1980) to construct the daily volatility $\left(V L_{t}\right)$ as follows

$$
V L_{t}=\frac{1}{2} u^{2}-(2 \ln 2-1) c^{2}, \quad t \in \mathbb{N},
$$

where $u$ and $c$ are the differences in the natural logarithms of the high and low, and of the closing and opening prices respectively. Figure 1 plots the Garman-Klass (GK) volatility from 1995 to 2005 .

Various measures of GK volatility have been employed by, among others, Daigler and Wiley (1999), Kawaller et al. (2001), Wang (2002), Chen and Daigler (2008) and Chen et al. (2006). Chou (2005) proposes a conditional autoregressive range (CARR) model for the range, defined as the difference between the high and low prices. In line with previous research, in what follows we model GK volatility as an autoregressive process taking into account the feedback from volume to volatility, dual long-memory characteristics and GARCH effects.

\section{2 | Trading activity}

We use the daily trading volume of foreign investors and eight different domestic investors, that is individual investors, securities companies, insurance companies, mutual funds, investment banks, commercial banks, savings banks and other companies. Trading volume is also aggregated into four categories based on investor type (institutional, individual) and access to the trading system (member, non-member). Specifically, the four aggregate categories used here are member institutional (securities companies), non-member institutional (insurance companies, mutual funds, investment banks, commercial banks, savings banks, other companies), nonmember individual and non-member foreign investors. We analyse each volume series from its buy and sell side, as well as its total ([buy+sell]/2). Further, we use the buy and sell volume series for the turnover and include this as a measure of buy and sell trades in our model. This is computed as the ratio of the value of shares bought or sold to the value of shares outstanding (see Campbell et al., 1993; Bollerlsev \& Jubinski, 1999). Because trading volume is non-stationary several detrending procedures for the volume data have been considered in the empirical finance literature (see Lobato and Velasco, 2000). We form a trend-stationary $\left(D T R_{t}\right)$ time series of log-turnover $\left(T R_{t}\right)$ by incorporating the procedure used by Campbell et al. (1993), who use a 100-day backward moving average as follows:

$$
D T R_{t}=\frac{T R_{t}}{\frac{1}{100} \sum_{i=1}^{100} T R_{t-i}} .
$$

This metric produces a time series that captures the change in the long-run movement in trading volume (see Brooks, 1998; Fung and Patterson, 1999). The moving average procedure is deemed to provide a reasonable compromise between computational ease and effectiveness. ${ }^{9}$ Figure 2 plots the total turnover volume from January 1995 to October 2005. 


\begin{tabular}{|c|c|c|c|c|c|}
\hline \multicolumn{6}{|c|}{ Panel A: Average buy volume as a percentage of total buy volume } \\
\hline Investor type & (1) & (2) & (3) & (4) & Total \\
\hline \multicolumn{6}{|l|}{ Period } \\
\hline 1995-97 & $5.1 \%$ & $12.1 \%$ & $76.9 \%$ & $5.9 \%$ & 510 \\
\hline $1998-00$ & $3.1 \%$ & $13.2 \%$ & $75.5 \%$ & $8.2 \%$ & 2,157 \\
\hline $2001-03$ & $2.3 \%$ & $10 \%$ & $49.8 \%$ & $37.9 \%$ & 3,607 \\
\hline $2004-05$ & $2.1 \%$ & $17.1 \%$ & $58.1 \%$ & $22.7 \%$ & 2,520 \\
\hline \multicolumn{6}{|c|}{ Panel B: Average sell volume as a percentage of total sell volume } \\
\hline Investor type & (1) & (2) & (3) & (4) & Total \\
\hline \multicolumn{6}{|l|}{ Period } \\
\hline $1995-97$ & $6.1 \%$ & $17.6 \%$ & $70.9 \%$ & $5.4 \%$ & 510 \\
\hline $1998-00$ & $3.5 \%$ & $14.2 \%$ & $75.4 \%$ & $6.9 \%$ & 2,157 \\
\hline $2001-03$ & $3.4 \%$ & $14.1 \%$ & $70.1 \%$ & $12.4 \%$ & 3,607 \\
\hline 2004-05 & $2.2 \%$ & $16.3 \%$ & $59.4 \%$ & $22.1 \%$ & 2,520 \\
\hline
\end{tabular}

TABLE 1 Trading volume by trader type (AFC period)

Note: This table presents daily average buy and sell volume statistics for four trader categories: Member Institutional (1), Non-member Institutional (2), Non-member Individual (3) and Nonmember Foreign (4). Panel A (B) shows the percentage breakdown of buy (sell) volume by category and the total daily volume (in trillion Korean won). Percentages sum to 100 over each period.

Table 1 reports the descriptive statistics of the breakdown of the total buy and sell volume into four trader categories. Average (daily) total trading volume is 510 trillion Korean Won for the 3 years ending in 1997. There is a fourfold increase in the average trading volume from 1998 to 2000 and it reaches the staggering amount of 3,607 trillion Won towards the end of 2003. This increase in trading volume across the years is not shared evenly among the different types of traders. Individual investors are the major players in the Korean Stock Exchange. From 1995 to 2000 nearly $75 \%$ of all buy and sell trades involve individual investors, while from 2000 onwards this percentage falls to near $50 \%$. The presence of foreign investors in the cash market increases significantly from 2001 to 2003, with the buy side reaching $37.9 \%$ of the total buy volume compared to an average of 7\% from 1995 to 2000 . The sell trades also increased during the same period, but not as much as the buy ones.

Member institutional investors' average percentage of buy trades was only $5.1 \%$ for the 3 years ending in 1997 and, thereafter, decreased to $2.1 \%$ for the 2 years ending in 2005. The sell side figures for the same investors are not very different. Finally, non-member institutional investors' trading was slightly above $10 \%$ until the end of 2003 , reaching a maximum of $17.1 \%$ by the end of our sample. Their sell trades are close to $15 \%$ of total sell volume across all the subperiods examined.

\section{3 | Structural changes}

We further examine whether the trader type buy and sell effects on volatility are robust to the AFC, which hit the major Asian economies at the end of 1997, and had repercussions until the end of 1998. It also brought about changes in the Korean Stock Exchange such as abolishing the foreign ownership ceiling, allowing free movement of the profit on investment and providing transparent financial reports. These developments, together with the introduction of index futures/options trading during the same period, raise interesting research questions about the impact of buy and sell trades on volatility. Another reason for investigating the after-crisis period is that foreign investors significantly increased their participation in stock trading. We test for structural breaks by employing the methodology of Bai and Perron (1998, 2003a,b), who address the problem of testing for multiple structural changes in a least-squares context and under very general conditions.

Our results (not reported) indicate two breaks for volatility. The first is detected in October 1997 and the second in November 2000. Accordingly, we split the sample into three sub-periods. The first is the pre-crisis period and spans from January 3, 1995, to October 15, 1997 (Subsample A hereafter). The second is the post-crisis period (including the in-crisis period and the economic recovery of Korea) and spans from the October 16, 1997, 
to the October 26, 2005 (Subsample B hereafter). The third goes from November 7, 2000, to the October 26, 2005, and is the post-crisis period (excluding the in-crisis sample) characterized by a world recession, which starts with the second break in volatility (Subsample B1 hereafter). The results for subsample B1 are totally consistent with those for Subsample B and are omitted for brevity's sake.

Subsample A can be characterized as the tranquil and pre-(currency) crisis period. This was the time when Korea was regarded as one of the miracle economies in East Asia, and foreign investors were enthusiastic about investing in the country. The first break in volatility is associated with the AFC in 1997. While Korea's own currency crisis would come later, in November of that year, the currency of Thailand, the Baht (and other currencies in Asia) was already the target of speculative attacks in June. The Thai Baht collapsed at the beginning of July, marking the beginning of what we now call the AFC. The Thai crisis sent repercussions throughout the region. Subsample B is the post-crisis period including the in-crisis period and the economic recovery. On November 18, 1997, the Bank of Korea gave up defending the Korean Won. On November 21, the Korean government asked the IMF for a bail-out. The Asian crisis effects lasted until the end of 1998 and, thereafter, the Asian markets and the economies began to recover despite the significant uncertainty related to emerging markets in Russia, South America and Asia in October 1998. In 19992000 the Korean economy achieved an early and strong recovery from the severe recession. After 2000 the Korean economy faced many economic and political challenges compounded by a global economic slowdown with hesitant recovery and domestic and global uncertainty ahead (Crotty and Lee, 2006). The internationalization of capital markets was reflected not only in the addition of foreign securities to otherwise domestic portfolios, but also in active trading in foreign markets (Dvořák, 2001). In the case of Korea, the share of foreign trading activity in total stock market volume and the foreign stock ownership increased significantly in the post-2000 period.

\section{4 | ESTIMATION PROCEDURES}

\section{1 | Estimation methodology}

Tsay and Chung (2000) have shown that regressions involving FI regressors can lead to spurious results. Moreover, in the presence of conditional heteroskedasticity Vilasuso (2001) suggests that causality tests can be carried out in the context of an empirical specification that models both the conditional means and conditional variances. Also, in many empirical applications the sum of the estimated variance parameters is often close to one, which implies integrated GARCH (IGARCH) behaviour. For example, Chen and Daigler (2008) emphasize that in most cases both variables exhibit significant persistence in their conditional variances. In particular, the sum of the variance parameters was at least 0.95. Most importantly, Baillie et al. (1996), using Monte Carlo simulations, show that data generated from a process exhibiting FIGARCH effects may be easily mistaken for IGARCH behaviour. Therefore, we focus our attention on long memory and persistence in terms of the second moments of volatility. Consequently, we utilize a univariate ARFI-FIGARCH model to test for the causal effect of volume on volatility. Next we discuss the dual long-memory model for volatility.

\section{2 | Dual long memory}

Let us first define the two variables. In the expression below the equation represents the GK volatility $\left(V L_{t}\right)$, where turnover volume $\left(T V_{t}\right)$ is added as a regressor. The $\operatorname{ARFI}\left(1, d_{m}\right)$ model for the conditional mean of volatility is given by

$$
(1-L)^{d_{m}} \phi(L)\left(V L_{t}-\varphi_{s} L^{s} T V_{t}-\mu\right)=\varepsilon_{t},
$$

where $L$ is the lag operator, $\phi(L)=1-\sum_{i=1}^{p} \phi_{i} L^{i}$ is the AR polynomial, and $0 \leq d_{m} \leq 1$. The $\varphi_{s}$ coefficient captures the effect from volume on volatility. We assume $\varepsilon_{t}$ is conditionally normal with mean 0 and variance $h_{t}$.

Further, the FIGARCH $\left(1, d_{v}, 1\right)$ process for the conditional variance of volatility is defined by

$$
(1-\beta L) h_{t}=\omega+\left[(1-\beta L)-(1-c L)(1-L)^{d_{v}}\right] \varepsilon_{t}^{2},
$$

where $\omega \in(0, \infty)$ and $0 \leq d_{v} \leq 1$. Note that the FIG$\mathrm{ARCH}$ model is not covariance stationary. Whether it is strictly stationary or not is still an open question at present (see Conrad and Haag, 2006). In the FIGARCH model, conditions on the parameters have to be imposed to ensure the non-negativity of the conditional variances (see Conrad and Haag, 2006 and Conrad, 2010). When $d_{v}=0$ the model reduces to the $\operatorname{GARCH}(1,1)$ model: $(1-\beta L) h_{t}=\omega+\alpha L \varepsilon_{t}^{2}$, where $\alpha=c-\beta$.

\section{5 | EMPIRICAL ANALYSIS}

\section{1 | Model characteristics}

Within the framework of the ARFI-FIGARCH model, we analyse the dynamic adjustments of both the conditional 
T A B L E 2 Mean equations: Fractional parameters $d_{m}$ (AFC period)

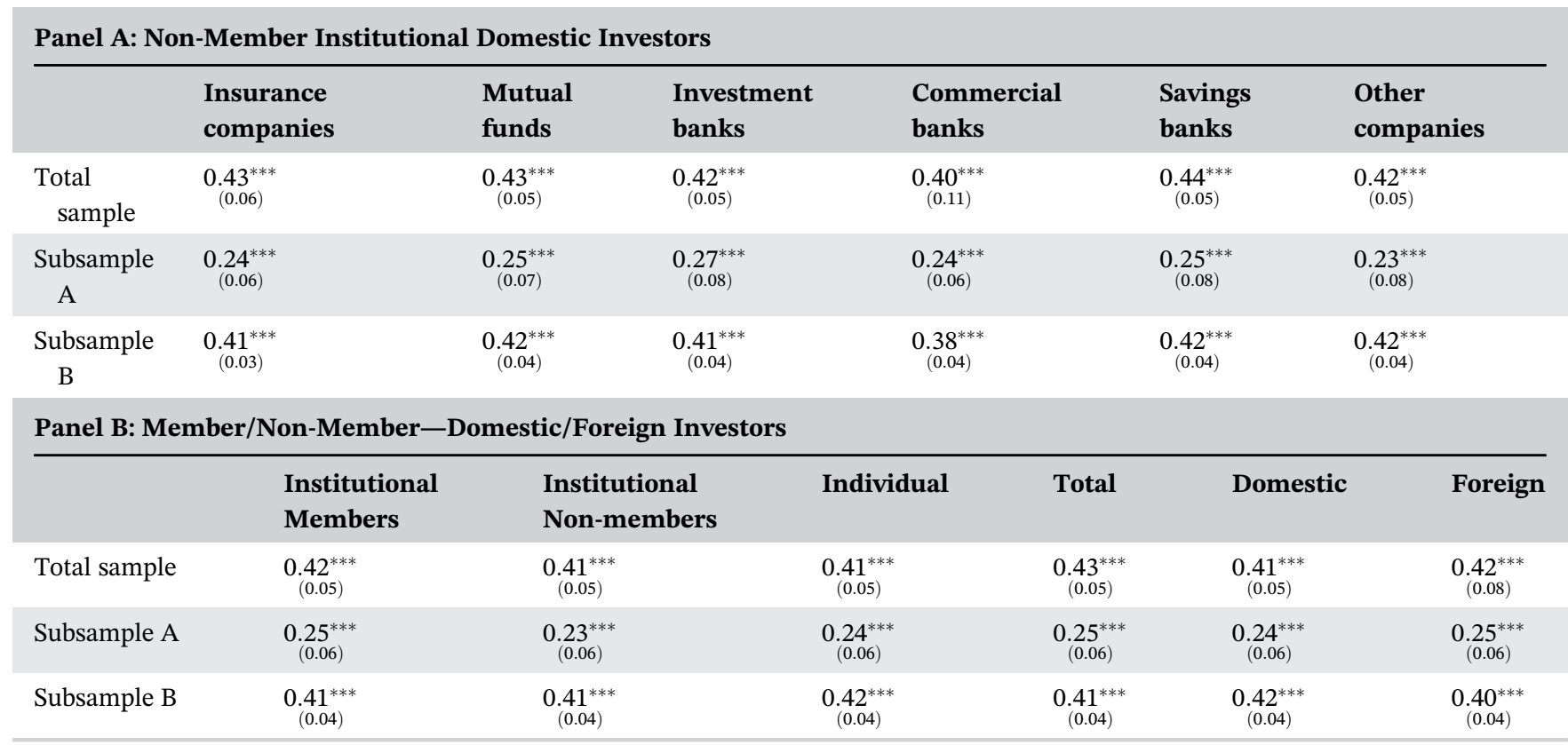

Notes: The table reports the fractional parameter estimates of the long memory in the mean equations. $d_{m}$ is defined in Equation (1). The estimates are reported only for the case when total volume is added as a regressor. Estimates with buy/sell volume as regressors are very similar to total volume. The estimates for subsample B1 are not reported for space reasons. *** denotes significance at the 0.01 level. The numbers in parentheses are standard errors.

TABLE 3 Variance equations: Fractional parameters $d_{v}$ (AFC period)

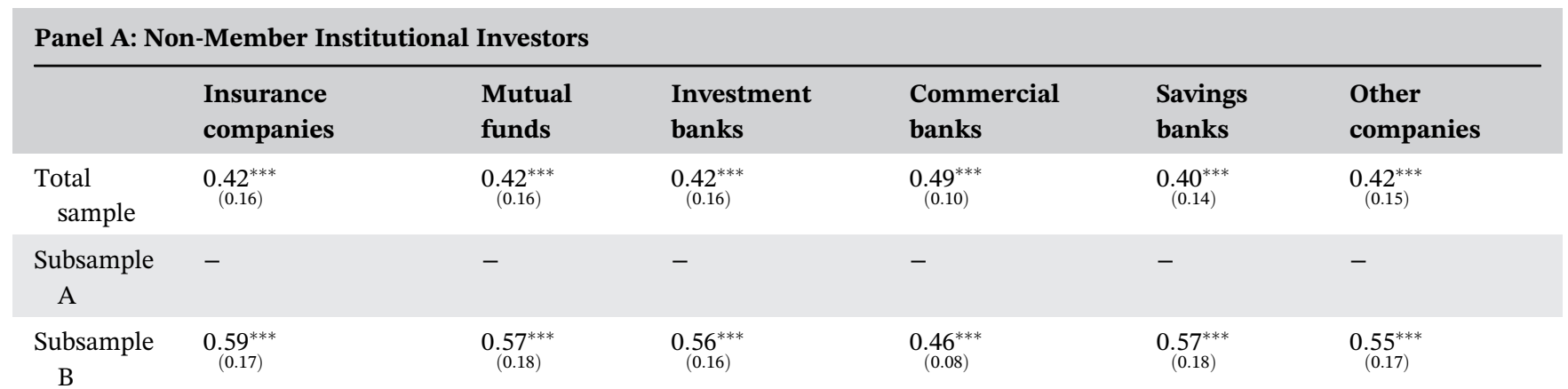

\begin{tabular}{|c|c|c|c|c|c|c|}
\hline & $\begin{array}{l}\text { Institutional } \\
\text { Members }\end{array}$ & $\begin{array}{l}\text { Institutional } \\
\text { Non-members }\end{array}$ & Individual & Total & Domestic & Foreign \\
\hline Total sample & $\underset{(0.16)}{0.42^{* * *}}$ & $\underset{(0.15)}{0.42^{* * *}}$ & $\begin{array}{c}0.43^{* * *} \\
(0.16)\end{array}$ & $\underset{(0.16)}{0.42^{* * *}}$ & $\underset{(0.16)}{0.43^{* * *}}$ & $\begin{array}{c}0.43^{* * *} \\
(0.17)\end{array}$ \\
\hline Subsample A & - & - & - & - & - & - \\
\hline Subsample B & $\begin{array}{c}0.57^{* * *} \\
(0.19)\end{array}$ & $\underset{(0.17)}{0.56^{* * *}}$ & $\begin{array}{c}0.57^{* * *} \\
(0.17)\end{array}$ & $\underset{(0.17)}{0.56^{* * *}}$ & $\begin{array}{c}0.56^{* * *} \\
(0.17)\end{array}$ & $\begin{array}{c}0.58^{* * *} \\
(0.18)\end{array}$ \\
\hline
\end{tabular}

Notes: The table reports the fractional parameter estimates of the long memory in the variance equations. $d_{v}$ is defined in Equation (2). The estimates are reported only for the case when total volume is added as a regressor. Estimates with buy/sell volume as regressors are very similar to total volume. The estimates of the subsample B1 are not reported for space reasons. *** denotes significance at the 0.01 level. The numbers in parentheses are standard errors.

mean and variance of volatility for all three AFC subsample periods and the entire sample, as well as the implications of these dynamics for the direction of causality from volume to volatility. The estimates of the various formulations were obtained by quasi-maximum likelihood estimation as implemented by James Davidson (2017) in time-series modelling. To check for the robustness of our estimates we used a range of starting 
T A B L E 4 Mean equations-Cross effects of Institutional Non-members (AFC period)

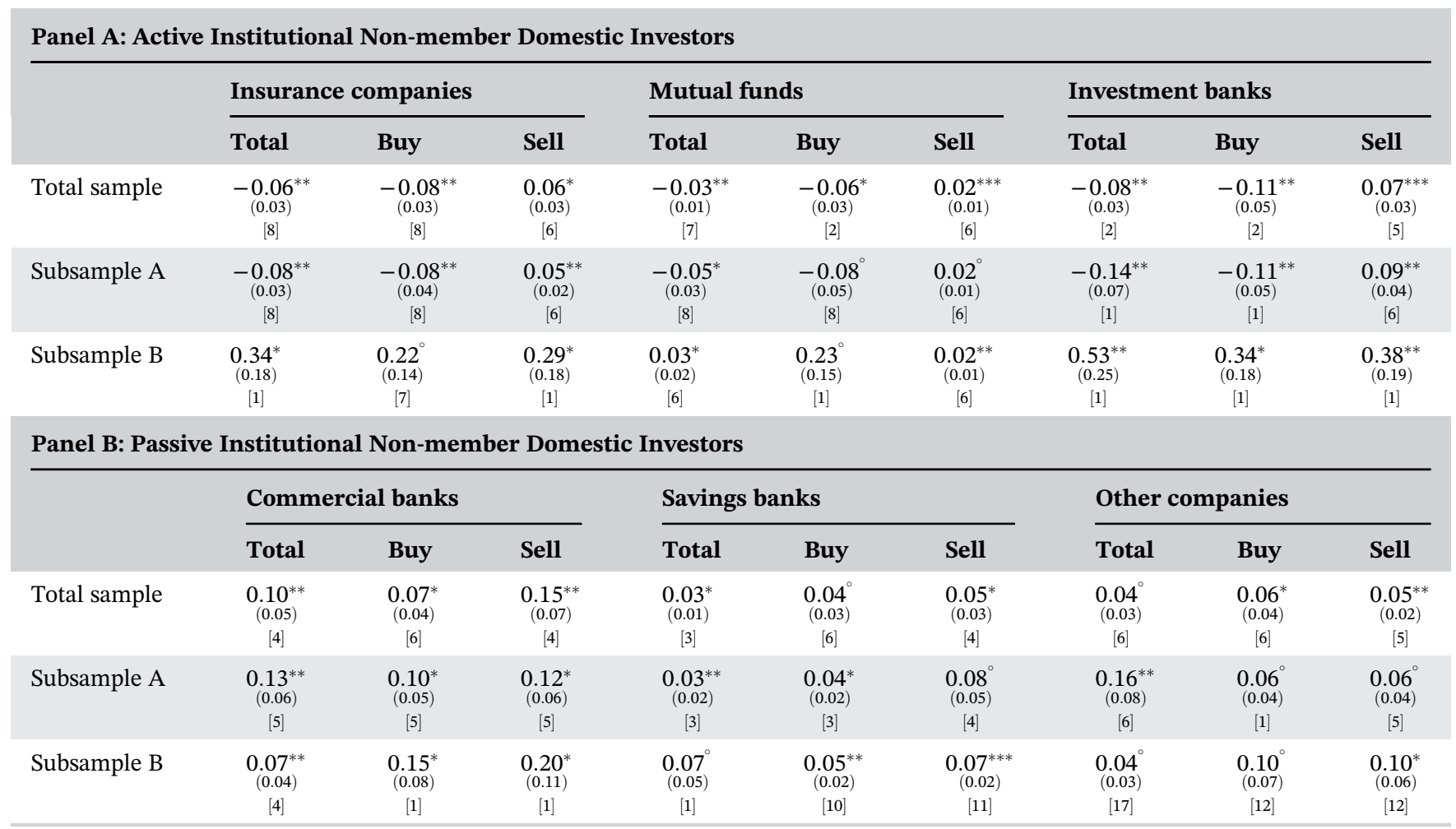

Note: The table reports parameter estimates of the cross effects $\varphi_{s}$ in the mean equations (as defined in (1)). The estimates of subsample B1 are not reported for space reasons. ***, **, *, and $\circ$ denote significance at the $0.01,0.05,0.10$, and 0.15 levels, respectively. The numbers in parentheses are standard errors. The numbers in brackets are the lag order $s$ of the regressor.

values and hence ensured that the estimation procedure converged to a global maximum.

The best-fitting specification (see Equation (1)) is chosen according to the minimum value of the information criteria. For the conditional mean of volatility $\left(V L_{t}\right)$, we choose an $\operatorname{ARFI}\left(3, d_{m}\right)$ process for the pre-crisis period and an $\operatorname{ARFI}\left(1, d_{m}\right)$ for the other two subsamples and the entire period. That is, $\phi(L)=1-\phi_{3} L^{3}$ and $\phi(L)=1$ $-\phi_{1} L$, respectively. We also calculate Ljung-Box Q statistics at 12 lags for the levels and squares of the standardized residuals for the estimated dual long-memory models. The test results show that the time-series models for the conditional mean and the conditional variance adequately capture the distribution of the disturbances. Autoregressive coefficients and test statistics are not reported for space considerations.

Moreover, we employ the diagnostic tests proposed by Engle and $\mathrm{Ng}$ (1993), which focus on the asymmetry of the conditional variance to news. According to the joint test of the size and sign bias, for the entire sample period, the sign and the negative size bias test statistics (not reported) for asymmetries in the conditional variance of volatility are significant. For the pre-crisis period (subsample A) there is no indication of asymmetry in the conditional variance. By contrast, for the post-crisis period (Subsample B) the results from the diagnostic tests point to the presence of a leverage effect in the conditional variance ${ }^{10}$.

Finally, the application of a bivariate extension of the dual long-memory model does not have an impact on the empirical findings produced by the univariate one.

\section{2 | Fractional mean parameters}

Estimates of the fractional mean parameters are shown in Table 2. In all cases, the estimated value of $d_{m}$ is robust to the measures of volume used ${ }^{11}$. In other words, all ARFI models for the subsamples generated very similar estimates of $d_{m}$. For example, in the total sample, the 12 long-memory mean parameters are between 0.40 and 0.44 . For the post-crisis period (Subsample B) the estimated values of $d_{m}(0.38-0.42)$ are similar to the total sample's estimates but higher than the corresponding values for the pre-crisis period (subsample A): $0.23-0.27$. Overall, we find that the 
T A B L E 5 Mean equations-Cross effects (AFC period)

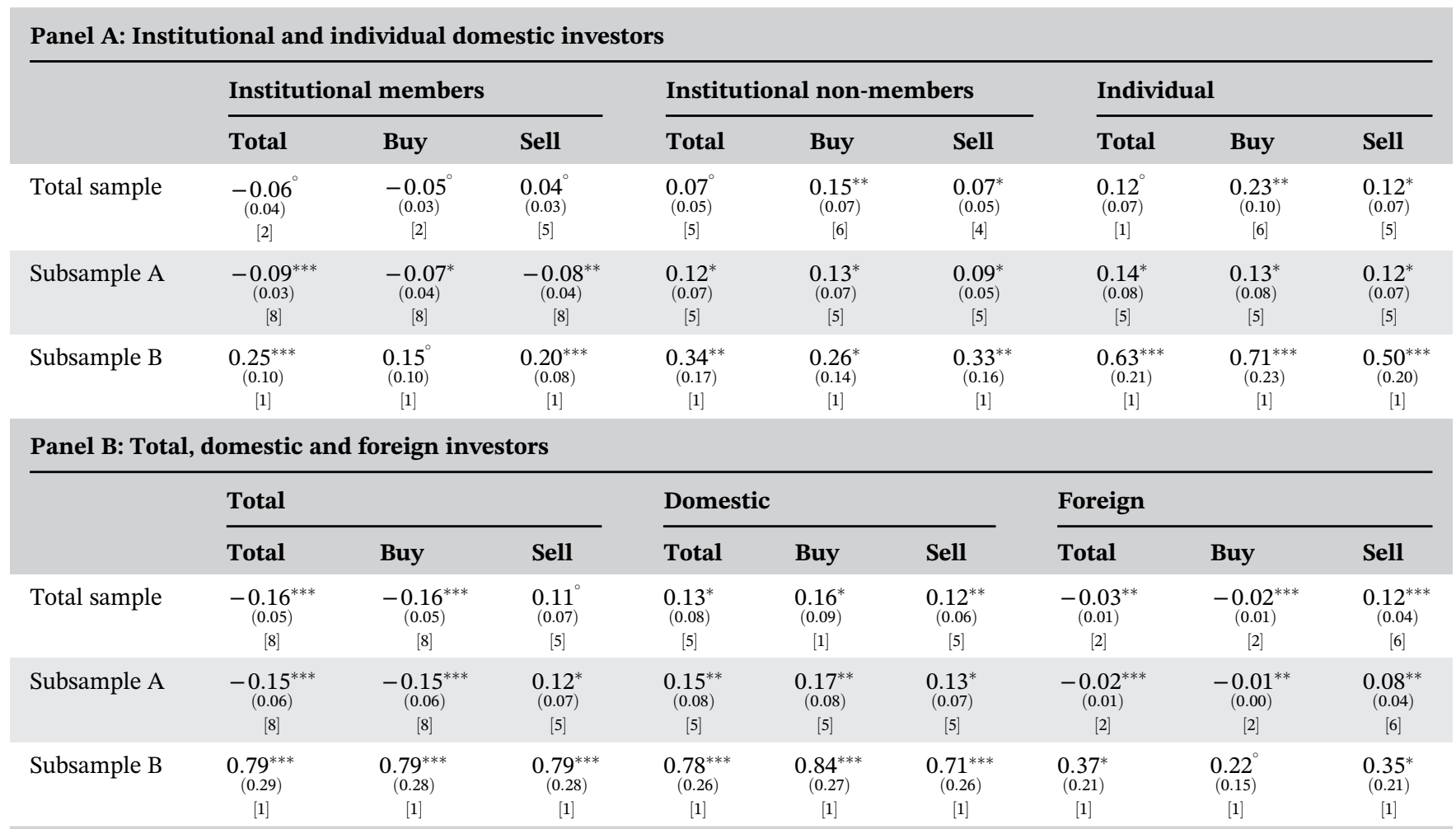

Note: See notes in Table 4.

apparent long-memory in volatility is quite robust to mean shifts.

\section{3 | FIGARCH specifications}

Table 3 presents the estimates of the fractional parameter of the FIGARCH model. The parameter $d_{v}$ governs the long-run dynamics of the conditional heteroskedasticity of volatility and is robust to the measures of volume used. In other words, all FIGARCH models for the various subsamples generated very similar fractional variance parameters. In the post-crisis period, these (0.55-0.59) are higher than the corresponding parameters for the total sample (0.40-0.43); in the case of commercial banks' turnover the estimate of $d_{v}$ for the total sample (0.49) is also higher than the corresponding one (0.46) lower for Subsample B. In the pre-crisis period the estimates of $d_{v}$ are close to and not significantly different from zero. In other words, the conditional variances are characterized by GARCH behaviour. Overall, when we allow for structural breaks the order of integration of the variance series decreases considerably, and in the pre-crisis period the long memory in variance disappears. Finally, the estimated values of the GARCH coefficients in the conditional variance are robust to the different volumes added as regressors (see the Appendix, Tables A1, A2). Note that in all cases the necessary and sufficient conditions for the non-negativity of the conditional variances are satisfied (see Conrad Haag, 2006).

\section{4 | Trade links with volatility}

To sum up, we employ the univariate ARFI-FIGARCH model with lagged values of volume included in the mean equation of volatility to test for causality. The estimated coefficients $\varphi_{s}$, defined in Equation (1), which capture the possible feedback between the two variables, are reported in Tables 4 and 5. We also tested the contemporaneous effect of volume on volatility adding the volume series in the volatility Equation (1) with lag order $s=0$. The estimated value of $\varphi_{0}$ (not reported) was always positive and significant, which indicates a positive contemporaneous effect of volume on volatility. Regarding the lags used to find the causal effect, we tested for the significance of up to the twentieth lag. The first two lags show an immediate causal effect of volume on volatility, lag order five indicates a one-week effect and so on. The twentieth lag points to a one-month in advance effect of the trading turnover volume on the market's volatility, which we interpret 
T A B L E 6 The volume-Volatility link (AFC period)

\begin{tabular}{|c|c|c|c|c|c|c|c|c|c|}
\hline \multicolumn{10}{|c|}{ Panel A: Active Institutional Non-member Domestic Investors } \\
\hline & \multicolumn{3}{|c|}{ Insurance companies } & \multicolumn{3}{|c|}{ Mutual funds } & \multicolumn{3}{|c|}{ Investment banks } \\
\hline & Total & Buy & Sell & Total & Buy & Sell & Total & Buy & Sell \\
\hline Total sample & - & - & + & - & - & + & - & - & + \\
\hline Subsample A & - & - & + & - & - & + & - & - & + \\
\hline Subsample B/B1 & + & + & + & + & + & + & + & + & + \\
\hline \multicolumn{10}{|c|}{ Panel B: Passive Institutional Non-member Domestic Investors } \\
\hline & \multicolumn{3}{|c|}{ Commercial banks } & \multicolumn{3}{|c|}{ Savings banks } & \multicolumn{3}{|c|}{ Other companies } \\
\hline & Total & Buy & Sell & Total & Buy & Sell & Total & Buy & Sell \\
\hline Total sample & + & + & + & + & + & + & + & + & + \\
\hline Subsample A & + & + & + & + & + & + & + & + & + \\
\hline Subsample B/B1 & + & + & + & + & + & + & + & + & + \\
\hline \multicolumn{10}{|c|}{ Panel C: Institutional and individual domestic investors } \\
\hline & \multicolumn{3}{|c|}{ Institutional (M) } & \multicolumn{3}{|c|}{ Institutional (NM) } & \multicolumn{3}{|c|}{ Individual } \\
\hline & Total & Buy & Sell & Total & Buy & Sell & Total & Buy & Sell \\
\hline Total sample & - & - & + & + & + & + & + & + & + \\
\hline Subsample A & - & - & - & + & + & + & + & + & + \\
\hline Subsample B/B1 & + & + & + & + & + & + & + & + & + \\
\hline \multicolumn{10}{|c|}{ Panel D: Total, domestic and foreign investors } \\
\hline & \multicolumn{3}{|l|}{ Total } & \multicolumn{3}{|c|}{ Domestic } & \multicolumn{3}{|c|}{ Foreign } \\
\hline & Total & Buy & Sell & Total & Buy & Sell & Total & Buy & Sell \\
\hline Total sample & - & - & + & + & + & + & - & - & + \\
\hline Subsample A & - & - & + & + & + & + & - & - & + \\
\hline Subsample B/B1 & + & + & + & + & + & + & + & + & + \\
\hline
\end{tabular}

as a weaker relationship between the two variables (i. e., other companies' total volume in Subsample B and securities companies-members' purchases in Subsample B). In most cases, we used up to eight lags to detect the causal effect. Likelihood ratio tests and information criteria have been used to choose the specification for the feedback from volume to volatility.

\subsection{1 | Institutional investors (non- members)}

Panels A and B of Table 4 give the results of the volume-volatility link for six different institutional domestic investor groups that are regarded as non-members of the market.

For the three active investors' (insurance companies, mutual funds, and investment banks) trades in the period after the AFC, we observe that buy and sell trades are associated with more volatility, possibly pointing towards momentum and positive feedback trading activities (thus, supporting H1a). However, their trades have an asymmetric feedback effect on volatility up to the AFC break, with buy orders having a stabilizing effect and sell orders a destabilizing one. Active investors are oriented towards trading and investing in stock markets and are more likely to spend extra resources to acquire and analyse important company fundamental and market-wide information (despite not holding a seat on the stock exchange). It seems that the buy decisions of this group of investors are more informative in terms of value, resulting in less price volatility for subsample A (in line with $\mathrm{H} 2 \mathrm{~b}$ ). The evidence for the whole sample suggests that, for the three active investors, the causal negative effect from total volume to volatility reflects the causal relation between buy trades and volatility in the pre-crisis period. 
T A B L E 7 The volume-Volatility link (GFC period)

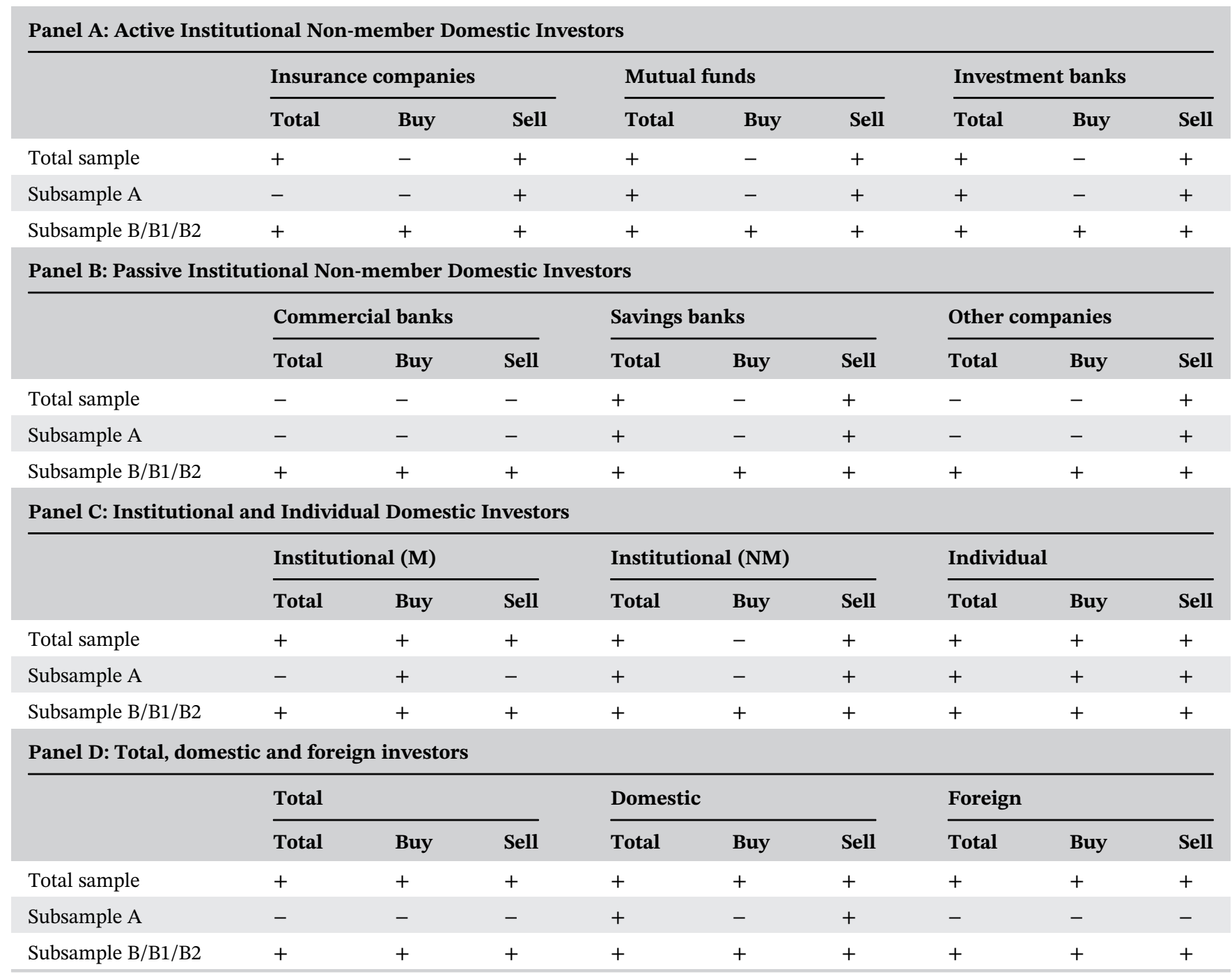

Commercial banks', savings banks' and other companies' buy and sell trades have a positive feedback effect on volatility for the whole sample as well as for the subsamples examined. This group of passive investors participates in the markets as a residual portfolio activity rather than as a core business operation, which is the acceptance of deposits and loan supply for banks. This positive buy and sell positive impact is more consistent with trades that contain less fundamental information (supporting $\mathrm{H} 2 \mathrm{a}$ ) as well as traders who engage in herding and positive feedback trades based on short-lived information (see again H1a).

To sum up, passive investors' trading volume is found to affect volatility positively, whereas active investors' total trading during the whole AFC period reduces volatility. This result is reversed in the GFC period (see Section 6). It is now worth looking at the aggregate buy and sell trading behaviour of members and non-members as well as that of individuals.

\subsection{2 | Institutional and individual (domestic) investors}

In Panel $\mathrm{A}$ of Table 5, non-member institutionals' buy and sell trades are aggregated and presented with the other two domestic investors, namely the member institutional (securities companies) and the individual investors. The non-member institutional and individual investors buy and sell trades affect volatility positively across all subsamples. Both types of investors are regarded here as less informed (see H2a) because they do not hold a seat on the Korean Stock Exchange and, as a result, they receive information about the order flow on a second-hand basis (recall here the argument of De Long et al. (1990) that in the presence of positive feedback traders, rational speculation (or trading by institutional non-member investors) can destabilize asset prices (H1a). The results for buy and sell trades of individuals increasing stock market volatility are also consistent with trades 
that are affected by psychological biases and carry less information (Barber and Odean, 2011).

Securities companies are members of the Korean Stock Exchange and they have direct access to the trading system. This gives an information advantage to this type of investors, as they have minute information about the supply and demand orders of the cash market. In the case of these companies, which are the most informed among domestic investors (and among the main liquidity providers), there is a negative impact on volatility through their purchases and sales in the pre-crisis period (in line with $\mathrm{H} 2 \mathrm{~b}$ ). However, this result is reversed when we consider the post-crisis period, where both buy and sell trades affect volatility positively. Overall, the evidence for the whole sample suggests that for institutional investors who are members the causal negative effect from total volume to volatility reflects the causal relation between buy trades and volatility in the pre-crisis period. It is now interesting to compare differences in the trading behaviour of domestic vs. foreign investors.

\subsection{3 | Domestic and foreign investors}

Panel B of Table 5 shows the effect of the total domestic and foreign buy and sell trades on volatility. Concerning the aggregated domestic investors' trading behaviour, we observe that both buy and sell trades exacerbate volatility over the whole period and the subsamples examined (that is, their behaviour is identical to that of the nonmember institutional and individual investors). This result is likely to be generated by herding or positive feedback trading (H1a) as well as uniformed trading (H2a). Interestingly, we see that when we construct the aggregate of all domestic investors we fail to recognize the negative effect of the purchase (and total) orders on volatility for institutional members. As for Subsample B, the positive impact in the case of domestic investors is consistent with the disaggregation of traders into institutional/individual, members/non-members institutional and to active/passive non-members institutional.

Regarding the foreign investors' trading behaviour, the foreign sell trades affect volatility positively (supporting H2a). The effect of buy trades on volatility switches from negative in the period up to the AFC to positive in the post-crisis period. It seems that foreign purchases are more informative than foreign sales. That is, foreign purchases are more value-motivated, while foreign sales are market phase or momentum-driven. These findings are in accordance with those of Wang (2007), who reported that foreign purchases tend to stabilize stock markets-by increasing the investor base in emerging markets-especially in the first few years after market liberalization when foreigners are buying into local markets.

Overall, the evidence for the whole sample suggests that the causal negative effect from total volume to volatility reflects the causal relationship between foreign buy trades and volatility in the pre-crisis period. This is in line with the results of Karanasos and Kartsaklas (2009), who show that the stabilizing impact of total volume on volatility comes from the foreign volume effect.

\subsection{4 | Summary}

Table 6 provides a summary of the volume-volatility link signs. The sell side of the trading activity (in all but one cases) as well as the post-crisis buy side and total trading activity in all volumes always exhibit a positive sign. This is consistent with the findings of Avramov et al. (2006), who concluded that sell herding trades increase volatility. For the pre-crisis period and the total sample, we observe the following: institutional non-members affect market volatility positively with their total and buy orders since the negative effect of active investors is overridden by the passive investors' positive impact. Institutional members' trading reduces volatility, a result which is consistent with the findings of Cai et al. (2010) and Li and Wang (2010) for the Chinese market. By contrast, the non-members and individuals destabilize the market. The former result is in line with those of Basak and Pavlova (2013) for the US, while the latter is consistent with those of Foucault et al. (2011) for France and Umutlu and Shackleton (2015) for Korea.

A positive link is the prevailing result for the domestic investors' trading activity when all domestic investor groups are aggregated. On the other hand, foreign investors stabilize the market with their total and buy orders, which is also reflected in the total volume (total and buy side) of all investors trading on the KOSPI 200 index for the entire 10-year period around the AFC and the pre-crisis subsample. This result confirms the findings in Wang (2007) for Indonesia and Thailand.

It is important to highlight here again that, overall, buy orders appear to be more informative and valuebased, while sell orders are less informative and more market phase driven. Additionally, the results suggest that the causal effect from volume to volatility is sensitive to structural changes. We find a uniform positive and significant link between buy/sell orders and volatility in the post-crisis period across all types of investors. However, in the pre-crisis period buy orders affect volatility negatively for various types of investors (member and active non-member institutional, and foreign). 


\section{6 | THE GFC PERIOD}

Following the empirical analysis of the volume effect on volatility around the Asian turmoil, we extend our investigation to the 2008 GFC in order to compare the two crises in terms of the trader-type effects on the Korean stock market volatility. Our GFC sample spans from the 26th of May 2006 to the 30th of December 2014 (2,133 observations). We calculate the detrended turnover volumes for the different investor categories and the GK volatility, similarly to the AFC period data. By carrying out the Bai and Perron tests, two breakpoints are detected for the volatility time series. The first break date is on October 29, 2008 and corresponds to the start of the crisis with the subprime market collapse. The second break is identified on $09 / 08 / 2011$, the initial financial turmoil lasting for years and being followed by the sovereign debt crisis in the Eurozone area. Therefore the two subsamples are defined as follows: i) Subsample A: May 26, 2006-October 29, 2008, the pre-crisis period until the first structural break. ii) Subsample B: October 30, 2008-December 30, 2014, the post-crisis period from the first break until the end of the sample, including the outset of the GFC and the sovereign debt crisis. iii) Subsample B1: October 30, 2008-09/08/2011, the post-crisis period between the two break dates, from the global crash until the beginning of the sovereign debt crisis. iv) Subsample B2: 10/08/2011December 30, 2014, the post-crisis period from the second break until the end of the sample, that is the late GFC period. The results for subsamples B1 and B2 are totally consistent with those for Subsample B and are omitted for space considerations.

We apply the ARFI-FIGARCH model, as in the AFC analysis, with volume regressors in the volatility mean equation for the entire sample and the subsamples A, B, B1 and B2. The best-fitting ARFI specifications for the mean equation are similar to the AFC results, with the $\operatorname{ARFI}\left(3, d_{m}\right)$ process chosen in the pre-crisis subsample A and the $\operatorname{ARFI}\left(1, d_{m}\right)$ process in the remaining periods. We present the GFC empirical evidence for the following investor groups: institutional members, institutional nonmembers (including the six different non-members separately), individuals, total domestic investors, foreign investors and total investors aggregated. The main results of the mean equation cross effects, long-memory parameters of the mean and the conditional variance and GARCH coefficients are presented in Tables B1-B4 of the Supplementary Appendix.

The sign analysis of the volume-volatility link for the different trader types and across the GFC time intervals (see Table 7) produces very interesting findings compared to the Asian turmoil evidence. The post-crisis subsamples always exhibit a positive link, as in the AFC respective subsamples. Similarly, there is a positive link in all cases for individual investors for both crises.

Overall, there are four main findings concerning the causal relationship between volume and volatility for the GFC vis-à-vis the AFC:

i) Concerning the signs, for the pre-crisis period and the total sample, from the six different institutional nonmembers separately, we observe stabilizing effects (for both purchases and total trades) from the passive nonmembers, whereas the total trades of the active ones increase volatility, which is the opposite effect compared to that implied by the AFC signs. Passive institutional non-members trading seems to use limit orders and pursue contrarian strategies, whereas the active ones are affected by momentum or engage in herding and positive feedback strategies in the GFC period, which is in accordance with our investment style hypotheses ( $\mathrm{H} 1 \mathrm{~b}$ and $\mathrm{H} 2 \mathrm{a}$, respectively).

ii) Stabilizing effects of the domestic institutional non-members' purchases in the global crash period, which is a result of the negative volume link for all six non-member categories buy side. This is also reflected in the fact that domestic investors' purchases activity lowers volatility in the pre-crisis period, a finding which is consistent with the results in Che (2018) for Norway, and those in Umutlu and Shackleton (2015) for the Korean market. The financial liberalization, deregulation and integration of the markets is more apparent during the last decade of the GFC period, while in the AFC decade the global integration process was still under development, with increasing foreign ownership. Consequently, we regard the non-members purchases as more informative in terms of value with less price volatility (investors analyse fundamentals and market-wide information) during the second crisis. This more sophisticated behaviour can be attributed to the higher degree of economic globalization and the massive advances in informationprocessing technology.

iii) Institutional members' total and buy trading exacerbates volatility in the entire global crash period.

iv) Similarly to iii) foreign investors' and total (where domestic and foreign investors are aggregated) volume have a positive impact on volatility. Given the commercial and financial integration at the global level, it is not surprising that foreign investors have a less apparent information advantage in the recent crisis than during the AFC.

\section{7 | CONCLUSIONS}

This paper has examined the long-run dynamics of stock market volatility using a dual long-memory model and it 
has investigated the effects of buy and sell trades by trader type in the Korean Stock Exchange during two crisis periods, the Asian one and the global crash. It has investigated whether these effects are robust to the financial crisis structural breaks.

Sales have been shown to exhibit a destabilizing effect on the market in most cases for both crises, confirming the result in Avramov et al. (2006) that sell herding trades increase volatility, whereas purchases seem to be more informative. During the post-crisis periods, the trading volume has been shown to increase volatility across all investor groups.

In the AFC domestic individual trades exacerbate volatility, a result which is consistent with the finding in Foucault et al. (2011) that noise trading leads to excess volatility. Domestic institutional investors are split into non-members, whose behaviour also has a destabilizing effect, and members with a stabilizing trading impact. This negative influence is consistent with the results in Umutlu and Shackleton (2015), who find that in Korea trading by informed domestic institutional investors reduces volatility. Inside the institutional non-members group, we observe that passive investors increase volatility, whereas the stabilizers are the active ones. Domestic investors' aggregate trading has a positive impact on volatility, reflecting the less informative trading of individuals and institutional non-members.

Foreign investors' buy orders have a stabilizing effect on volatility in the AFC, which is in accordance with value-motivated purchase decisions. These findings are in line with Wang (2007), who finds that foreign purchases tend to stabilize stock markets by increasing the investor base in emerging markets, especially in the first few years after market liberalization when foreigners are buying into local markets. The negative impact of total trading on volatility is determined by the foreign investors' purchases. Interestingly, in the GFC both buy and sell trades from foreign investors, and, as a result, total volume as well, affect volatility positively. This destabilizing impact is consistent with the results in Choe et al. (1999), Froot et al. (2001), and Che (2018), who find that foreign investors are momentum traders. They also confirm the results for the Korean market by Choe et al. (2005), who find that foreign investors are less informed, and by Jeon and Moffet (2010), who find that foreign investors in Korea are involved in hedging and positive feedback strategies.

Another major difference between the two crises is that in the global crash, all six active and passive investors have a stabilizing impact with their purchases, which mirrors the negative effect of the institutional non-members' purchases. Regarding total trading, inside the institutional non-members group, we observed that active investors lowered volatility in the Asian financial turmoil, while for the most recent crisis the stabilizers are the passive non-members, which confirms the hypothesis that passive traders use limit orders and engage in contrarian trades $(H 1 b)$. In addition, the destabilizing effect of active (total) trading on volatility during the global crash is consistent with herding and positive feedback trades based on short-lived information ( $\mathrm{H} 1 \mathrm{a})$.

Overall, our results suggest that the buy and sell trades can have an asymmetric effect on volatility, which depends on the type of investor trading and on the economic cycle's phase. Lastly, we find that the apparent long memory in volatility is quite robust to mean shifts. However, when we take into account structural breaks the order of integration of the conditional variance series decreases considerably.

\section{DATA AVAILABILITY STATEMENT}

The data that support the findings of this study are available from the corresponding author upon reasonable request.

\section{ORCID}

Guglielmo Maria Caporale (1) https://orcid.org/0000-00020144-4135

\section{ENDNOTES}

${ }^{1}$ See also other investor sentiment studies such as $\mathrm{Yu}$ and Yuan (2011), Stambaugh et al. (2012), Antoniou et al. (2013), and Shen et al. (2017).

2 Thomas et al. (2014) in their study on institutional investors focus on pension funds' activity and provide evidence on the negative relationship between pension funds' stock investments and stock market volatility in a wide range of OECD countries.

${ }^{3}$ Similarly, Cella et al. (2013) focus on the investment horizon of institutional investors in the US. During crisis periods, short-horizon institutional sales lead to larger price drops and reversals than long-term institutional trading, which means excess volatility. Among the researchers exploring investors' sentiments in the US market, Wang (2018) and DeVault et al. (2019) demonstrate that institutional traders are highly driven by sentiment in their trading activity exhibiting bounded rationality.

${ }^{4}$ Likewise, Choe et al. (1999) and Froot et al. (2001) find that foreign investors tend to be momentum investors.

${ }^{5}$ Choe et al. (2005) demonstrate that foreign investors are characterized by an information disadvantage compared to domestic ones.

${ }^{6}$ Source: Korean Stock Exchange Fact Book 2014-15.

${ }^{7}$ Source: MSCI Global Market Accessibility Review, June 2019.

${ }^{8}$ Source: Classifying South Korea as a Developed Market, January 2013, White Paper Report FTSE Publications by Woods, C.

${ }^{9}$ It was necessary (in order to obtain any results) to use an outlier reduced series for Savings banks Sell Turnover and Other companies Sell Turnover: the variance of the detrended data is 
estimated, and any value outside four standard deviations is replaced by four standard deviations. Chebyshev's inequality is used as it i) gives a bound of what percentage $\left(1 / k^{2}\right)$ of the data falls outside of $k$ standard deviations from the mean, ii) makes no assumption about the distribution of the data, and iii) provides a good description of the closeness to the mean, especially when the data are known to be unimodal as in our case.

10 To check the sensitivity of our results to different error distributions, we re-estimate our dual long-memory GARCH models using the skewed-t density with asymmetries. The results of the volume-volatility link are identical to those reported for the normal distribution (these results are available upon request).

${ }^{11}$ In addition, we test the hypothesis of long-memory following Robinson's (1995) semiparametric bivariate approach and the results are consistent with the parametric ones.

\section{REFERENCES}

Abbes, M. B. (2013). Does Overconfidence Bias Explain Volatility During the Global Financial Crisis? Transition Studies Review, 19, 291-312.

Alexander, G., Cici, G., \& Gibson, S. (2007). Does motivation matter when assessing trade performance? An analysis of mutual funds. Review of Financial Studies, 20, 125-150.

Anderson, A. (2013). Trading and under-diversification. Review of Finance, 17, 1699-1741.

Antoniou, C., Doukas, J. A., \& Subrahmanyam, A. (2013). Cognitive dissonance, sentiment, and momentum. Journal of Financial and Quantitative Analysis, 48, 245-275.

Avramov, D., Chordia, T., \& Goyal, A. (2006). The impact of trades on daily volatility. Review of Financial Studies, 19, 1241-1277.

Bae, S. C., Min, J. H., \& Jung, S. (2011). Trading Behavior, Performance, and Stock Preference of Foreigners, Local Institutions, and Individual Investors: Evidence from the Korean Stock Market. Asia-Pacific Journal of Financial Studies, 40, 199-239.

Bai, J., \& Perron, P. (1998). Estimating and testing linear models with multiple structural changes. Econometrica, 66, 47-78.

Bai, J., \& Perron, P. (2003a). Computation and analysis of multiple structural change models. Journal of Applied Econometrics, 18, $1-22$.

Bai, J., \& Perron, P. (2003b). Critical values for multiple structural change tests. The Econometrics Journal, 6, 72-78.

Baillie, R., Bollerslev, T., \& Mikkelsen, H. (1996). Fractionally integrated generalized autoregressive conditional heteroskedasticity. Journal of Econometrics, 74, 3-30.

Baker, M., \& Wurgler, J. (2006). Investor sentiment and the crosssection of stock returns. Journal of Finance, 61, 1645-1680.

Baker, M., \& Wurgler, J. (2007). Investor sentiment in the stock market. Journal of Economic Perspectives, 21, 129-152.

Barber, B., Lee, Y., Liu, Y., \& Odean, T. (2009). Just how much do individual investors lose by trading? Review of Financial Studies, 22, 609-632.

Barber, B., \& Odean, T. (2008). All that glitters: The effect of attention on the buying behavior of individual and institutional investors. Review of Financial Studies, 21, 785-818.

Barber, B., \& Odean, T. (2011). The behavior of individual investors. In G. M. Constantinides, M. Harris, \& R. M. Stulz (Eds.), Handbook of the Economics of Finance (pp. 1533-1570). North Holland, Amsterdam: Elsevier.
Barber, B., Odean, T., \& Zhu, N. (2009a). Do retail trades move markets? Review of Financial Studies, 22, 151-186.

Barber, B., Odean, T., \& Zhu, N. (2009b). Systematic noise. Journal of Financial Markets, 12, 547-569.

Basak, S., \& Pavlova, A. (2013). Asset prices and institutional investors. American Economic Review, 103, 1728-1758.

Black, F. (1986). Noise. Journal of Finance, 41, 529-543.

Bollerslev, T., \& Jubinski, D. (1999). Equity trading volume and volatility: Latent information arrivals and common long-run dependencies. Journal of Business \& Economic Statistics, 17, 9-21.

Brennan, M., \& Cao, H. (1997). International portfolio investment flows. Journal of Finance, 52, 1851-1880.

Brooks, C. (1998). Predicting stock index volatility: Can market volume help? Journal of Forecasting, 17, 59-80.

Cai, J., He, J., \& He, J. (2010). How better informed are the institutional investors? Economics Letters, 106, 234-237.

Campbell, J., Grossman, S., \& Wang, J. (1993). Trading volume and serial correlation in stock returns. Quarterly Journal of Economics, 108, 905-939.

Cella, C., Ellul, A., \& Giannetti, M. (2013). Investors' horizons and the amplification of market shocks. Review of Financial Studies, $26,1607-1648$.

Che, L. (2018). Investor types and stock return volatility. Journal of Empirical Finance, 47, 139-161.

Chen, Z., \& Daigler, R. (2008). An examination of the complementary volume-volatility information theories. Journal of Futures Markets, 28, 962-992.

Chen, Z., Daigler, R., \& Parhizgari, A. (2006). Persistence of volatility in futures markets. Journal of Futures Markets, 26, 571-594.

Chen, Z., Du, J., Li, D., \& Ouyang, R. (2013). Does foreign institutional ownership increase return volatility? Evidence from China. Journal of Banking \& Finance, 37, 660-669.

Choe, H., Kho, B., \& Stulz, R. (1999). Do foreign investors destabilize stock markets? The Korean experience in 1997. Journal of Financial Economics, 54, 227-264.

Choe, H., Kho, B., \& Stulz, R. (2005). Do domestic investors have an edge? The trading experience of foreign investors in Korea. Review of Financial Studies, 18, 795-829.

Chou, R. (2005). Forecasting financial volatilities with extreme values: The conditional autoregressive range (CARR) model. Journal of Money, Credit, and Banking, 37, 561-582.

Chuang, W.-I., Liu, H.-H., \& Susmel, R. (2012). The bivariate $\mathrm{GARCH}$ approach to investigating the relation between stock returns, trading volume, and return volatility. Global Finance Journal, 23, 1-15.

Conrad, C. (2010). Non-negativity conditions for the hyperbolic GARCH model. Journal of Econometrics, 157, 441-457.

Conrad, C., \& Haag, B. (2006). Inequality constraints in the fractionally integrated GARCH model. Journal of Financial Econometrics, 4, 413-449.

Crotty, J., \& Lee, K. (2006). The effects of neoliberal "reforms" on the post-crisis Korean economy. Review of Radical Political Economics, 38(3), 381-387.

Daigler, R., \& Wiley, M. (1999). The Impact of trader type on the futures volatility-volume relation. Journal of Finance, 54, 22972316.

Daniel, K., Hirshleifer, D., \& Subrahmanyam, A. (1998). Investor psychology and security market under- and overreactions. Journal of Finance, 53, 1839-1885. 
Davidson J., 2017. Time Series Modelling. http://www. timeseriesmodelling.com.

De Long, B., Shleifer, A., Summers, L., \& Waldmann, R. (1990). Positive feedback investment strategies and destabilizing rational speculation. Journal of Finance, 45, 379-395.

DeVault, L., Sias, R., \& Starks, L. (2019). Sentiment metrics and investor demand. Journal of Finance, 74, 985-1024.

Dvořák, T. (2001). Does foreign trading destabilize local stock markets? Unpublished paper, Department of Economics. Williamstown, Massachusetts: Williams College.

Easley, D., Kiefer, N., \& O'Hara, M. (1997). The information content of the trading process. Journal of Empirical Finance, 4, 159-186.

Easley, D., \& O'Hara, M. (1987). Price, trade size, and information in securities markets. Journal of Financial Economics, 19, 69-90.

Engle, R., \& Ng, V. (1993). Measuring and testing the impact of news on volatility. Journal of Finance, 48, 1749-1778.

Foucault, T., Sraer, D., \& Thesmar, D. (2011). Individual investors and volatility. Journal of Finance, 66, 1369-1406.

Froot, K., O'Connell, P., \& Seasholes, M. (2001). The portfolio flows of international investors. Journal of Financial Economics, 59, 151-193.

Fung, H., \& Patterson, G. (1999). The dynamic relationship of volatility, volume, and market depth in currency futures markets. Journal of International Financial Markets, Institutions and Money, 9, 33-59.

Garman, M., \& Klass, M. (1980). On the estimation of security price volatilities from historical data. Journal of Business, 53, 67-78.

Gervais, S., \& Odean, T. (2001). Learning to be overconfident. Review of Financial Studies, 14, 1-27.

Girard, E., \& Biswas, R. (2007). Trading volume and market volatility: Developed versus emerging stock markets. The Financial Review, 42, 429-459.

Goetzmann, W., \& Kumar, A. (2008). Equity portfolio diversification. Review of Finance, 12, 433-463.

Grinblatt, M., \& Keloharju, M. (2001). What makes investors trade? Journal of Finance, 56, 589-616.

Jeon, J. Q., \& Moffett, C. M. (2010). Herding by foreign investors and emerging market equity returns: Evidence from Korea. International Review of Economics and Finance, 19, 698-710.

Karanasos, M., \& Kartsaklas, A. (2009). Dual long-memory, structural breaks and the link between turnover and the range-based volatility. Journal of Empirical Finance, 16, 838-851.

Kawaller, I., Koch, P., \& Peterson, J. (2001). Volume and volatility surrounding quarterly redesignation of the lead S\&P 500 futures contract. Journal of Future Markets, 21(12), 1119-1149.

Kelley, E., \& Tetlock, P. (2013). Why do investors trade? Unpublished paper. New York City, NY: Columbia Business School.

Kim, J., Kartsaklas, A., \& Karanasos, M. (2005). The volume-volatility relationship and the opening of the Korean stock market to foreign investors after the financial turmoil in 1997. AsiaPacific Finanial Markets, 12, 245-271.

Koutmos, G., \& Saidi, R. (2001). Positive feedback trading in emerging capital markets. Applied Financial Economics, 11, 291-297.

Lakonishok, J., Shleifer, A., \& Vishny, R. (1992). The impact of institutional trading on stock prices. Journal of Financial Economics, 32, 23-43.
Li, W., \& Wang, S. S. (2010). Daily institutional trades and stock price volatility in a retail investor dominated emerging market. Journal of Financial Markets, 13, 448-474.

Lobato, I., \& Velasco, C. (2000). Long memory in stock-market trading volume. Journal of Business \& Economic Statistics, 18, 410-427.

Odean, T. (1998). Are investors reluctant to realize their losses? Journal of Finance, 53, 1775-1798.

Pisedtasalasai, A., \& Gunasekarage, A. (2007). Causal and dynamic relationships among stock returns, return volatility and trading volume: Evidence from emerging markets in South-East Asia. Asia-Pacific Financial Markets, 14, 277-297.

Robinson, P. (1995). Log-periodogram regression of time series with long-range dependence. Annals of Statistics, 23, 1048-1072.

Shen, J., Yu, J., \& Zhao, S. (2017). Investor sentiment and economic forces. Journal of Monetary Economics, 86, 1-21.

Stambaugh, R. F., Yu, J., \& Yuan, Y. (2012). The short of it: Investor sentiment and anomalies. Journal of Financial Economics, 104, 288-302.

Thomas, A., Spataro, L., \& Mathew, N. (2014). Pension funds and stock market volatility: An empirical analysis of OECD countries. Journal of Financial Stability, 11, 93-103.

Tsay, W., \& Chung, C. (2000). The spurious regression of fractionally integrated processes. Journal of Econometrics, 96, 155-182.

Umutlu, M., \& Shackleton, M. B. (2015). Stock-return volatility and daily equity trading by investor groups in Korea. Pacific-Basin Finance Journal, 34, 43-70.

Vilasuso, J. (2001). Causality tests and conditional heteroscedasticity: Monte Carlo evidence. Journal of Econometrics, 101, 25-35.

Wang, C. (2002). Information, trading demand and futures price volatility. Financial Review, 37, 295-316.

Wang, J. (2007). Foreign equity trading and emerging market volatility: Evidence from Indonesia and Thailand. Journal of Development Economics, 84, 798-811.

Wang, W. (2018). The mean-variance relation and the role of institutional investor sentiment. Economics Letters, 168, 61-64.

Yang, H., Ryu, D., \& Ryu, D. (2017). Investor sentiment, asset returns and firm characteristics: Evidence from the Korean stock market. Investment Analysts Journal, 46, 132-147.

Yu, J., \& Yuan, Y. (2011). Investor sentiment and the mean-variance relation. Journal of Financial Economics, 100, 367-381.

\section{SUPPORTING INFORMATION}

Additional supporting information may be found online in the Supporting Information section at the end of this article.

How to cite this article: Caporale GM, Karanasos M, Yfanti S, Kartsaklas A. Investors' trading behaviour and stock market volatility during crisis periods: A dual long-memory model for the Korean Stock Exchange. Int J Fin Econ. 2021;26:4441-4461. https://doi.org/10.1002/ ijfe.2024 


\section{APPENDIX A.}

\section{Panel A: Active institutional non-member domestic investors}

\begin{tabular}{|c|c|c|c|c|c|c|}
\hline & \multicolumn{2}{|c|}{ Insurance companies } & \multicolumn{2}{|c|}{ Mutual funds } & \multicolumn{2}{|c|}{ Investment banks } \\
\hline & $\alpha$ & $\beta$ & $\alpha$ & $\beta$ & $\alpha$ & $\beta$ \\
\hline Total sample & $\begin{array}{c}-0.16 \\
(0.15)\end{array}$ & $\underset{(0.22)}{0.59^{* * *}}$ & $\begin{array}{c}-0.16 \\
(0.15)\end{array}$ & $\underset{(0.23)}{0.59^{* * *}}$ & $\begin{array}{c}-0.16 \\
(0.15)\end{array}$ & $\underset{(0.23)}{0.59^{* * *}}$ \\
\hline Subsample A & $\begin{array}{l}0.15 \\
(0.16)\end{array}$ & $\underset{(0.22)}{0.72^{* * *}}$ & $\begin{array}{l}0.14 \\
(0.22)\end{array}$ & $\begin{array}{c}0.73^{* *} \\
(0.32)\end{array}$ & $\begin{array}{l}0.23 \\
(0.28)\end{array}$ & $\underset{(0.33)}{0.61^{*}}$ \\
\hline Subsample B & $\begin{array}{c}-0.29^{*} \\
(0.17)\end{array}$ & $\underset{(0.16)}{0.70^{* * *}}$ & $\begin{array}{c}-0.26^{*} \\
(0.16)\end{array}$ & $\underset{(0.21)}{0.71^{* * *}}$ & $\begin{array}{c}-0.25^{*} \\
(0.14)\end{array}$ & $\underset{(0.20)}{0.71^{* * *}}$ \\
\hline \multicolumn{7}{|c|}{ Panel B: Passive Institutional Non-member Domestic Investors } \\
\hline & \multicolumn{2}{|c|}{ Commercial banks } & \multicolumn{2}{|c|}{ Savings banks } & \multicolumn{2}{|c|}{ Other companies } \\
\hline & $\alpha$ & $\beta$ & $\alpha$ & $\beta$ & $\alpha$ & $\beta$ \\
\hline Total sample & -0.15 & $\underset{(0.21)}{0.55^{* * *}}$ & $\begin{array}{c}-0.17 \\
(0.14)\end{array}$ & $\begin{array}{c}0.52^{*} \\
(0.27)\end{array}$ & $\begin{array}{c}-0.16 \\
(0.15)\end{array}$ & $\frac{0.60^{* * *}}{(0.21)}$ \\
\hline Subsample A & $\begin{array}{l}0.16 \\
(0.26)\end{array}$ & $\begin{array}{c}0.73^{* *} \\
(0.35)\end{array}$ & $\begin{array}{l}0.16 \\
(0.25)\end{array}$ & $\begin{array}{c}0.71^{* *} \\
(0.35)\end{array}$ & $\begin{array}{l}0.17 \\
(0.15)\end{array}$ & $\begin{array}{c}0.74^{* * *} \\
(0.18)\end{array}$ \\
\hline Subsample B & $\underset{(0.11)}{-0.11}$ & $\underset{(0.16)}{0.59^{* * *}}$ & $\begin{array}{c}-0.27^{*} \\
(0.16)\end{array}$ & $\underset{(0.19)}{0.71^{* * *}}$ & $\begin{array}{l}-0.25^{*} \\
(0.15)\end{array}$ & $\underset{(0.23)}{0.69^{* * *}}$ \\
\hline
\end{tabular}

Notes: The table reports estimates of the $\operatorname{ARCH}(\alpha)$ and GARCH $(\beta)$ parameters in the variance equations. $\alpha, \beta$ are defined in Equation (2). The estimates are reported only for the case when total $T V_{t}$ is added as regressor and not for the buy-sell side of each series, The estimates of the subsample B1 are not reported for space reasons. ***, **, *, and $\circ$ denote significance at the 0.01 , $0.05,0.10$, and 0.15 levels, respectively. The numbers in parentheses are standard errors.

\begin{tabular}{|c|c|c|c|c|c|c|}
\hline \multicolumn{7}{|c|}{ Panel A: Institutional and individual domestic investors } \\
\hline & \multicolumn{2}{|c|}{ Institutional (M) } & \multicolumn{2}{|c|}{ Institutional (NM) } & \multicolumn{2}{|c|}{ Individual } \\
\hline & $\alpha$ & $\beta$ & $\alpha$ & $\beta$ & $\alpha$ & $\beta$ \\
\hline Total sample & $\begin{array}{c}-0.16 \\
(0.15)\end{array}$ & $\begin{array}{c}0.59^{* *} \\
(0.24)\end{array}$ & $\begin{array}{c}-0.16 \\
(0.15)\end{array}$ & $\frac{0.60^{* * *}}{(0.21)}$ & $\begin{array}{c}-0.16 \\
(0.15)\end{array}$ & $\frac{0.60^{* * *}}{(0.23)}$ \\
\hline Subsample A & $\begin{array}{l}0.13 \\
(0.12)\end{array}$ & $\begin{array}{c}0.76^{* * *} \\
(0.18)\end{array}$ & $\begin{array}{l}0.16 \\
(0.28)\end{array}$ & $\begin{array}{c}0.71^{*} \\
(0.38)\end{array}$ & $\begin{array}{l}0.14 \\
(0.17)\end{array}$ & $\begin{array}{c}0.75^{* * *} \\
(0.26)\end{array}$ \\
\hline Subsample B & $\begin{array}{c}-0.26^{\circ} \\
(0.16)\end{array}$ & $\underset{(0.22)}{0.72 * * *}$ & ${ }_{(0.15)}^{-0.25^{*}}$ & $\underset{(0.20)}{0.72^{* * *}}$ & $\begin{array}{c}-0.26^{*} \\
(0.15)\end{array}$ & $\underset{(0.22)}{0.71^{* * *}}$ \\
\hline \multicolumn{7}{|c|}{ Panel B: Total, domestic and foreign investors } \\
\hline & \multicolumn{2}{|l|}{ Total } & \multicolumn{2}{|c|}{ Domestic } & \multicolumn{2}{|l|}{ Foreign } \\
\hline & $\alpha$ & $\beta$ & $\alpha$ & $\beta$ & $\alpha$ & $\beta$ \\
\hline Total sample & $\frac{-0.16}{(0.15)}$ & $\underset{(0.21)}{0.60^{* * *}}$ & $\begin{array}{l}-0.16 \\
(0.15)\end{array}$ & $\frac{0.61^{* * *}}{(0.22)}$ & $\begin{array}{l}-0.16 \\
(0.15)\end{array}$ & $\underset{(0.24)}{0.61^{* * *}}$ \\
\hline Subample A & $\begin{array}{l}0.14 \\
(0.15)\end{array}$ & $\underset{(0.22)}{0.74^{* * *}}$ & $\begin{array}{l}0.13 \\
(0.16)\end{array}$ & $\begin{array}{c}0.76^{* * *} \\
(0.24)\end{array}$ & $\begin{array}{l}0.11 \\
(0.10)\end{array}$ & $\begin{array}{c}0.78^{* * *} \\
(0.16)\end{array}$ \\
\hline Subsample B & $\begin{array}{c}-0.25^{*} \\
(0.15)\end{array}$ & $\begin{array}{c}0.72^{* * *} \\
(0.21)\end{array}$ & $\begin{array}{c}-0.25^{*} \\
(0.15)\end{array}$ & $\begin{array}{c}0.71^{* * * *} \\
(0.22)\end{array}$ & $\frac{-0.25^{*}}{(0.16)}$ & $\begin{array}{c}0.73^{* * *} \\
(0.21)\end{array}$ \\
\hline
\end{tabular}

Notes: See notes in Table A1.
TABLE A1 Variance equations: GARCH coefficients (AFC period)
TABLE A2 Variance equations: GARCH coefficients (AFC period) 
T A B LE A3 The impact of volume on volatility: A summary of papers

\begin{tabular}{|c|c|c|c|c|}
\hline Investor categories & Authors & Countries & Impact & Hypothesis \\
\hline \multirow[t]{6}{*}{ Institutional } & Daigler and Wiley (1999) & US & - & $\mathrm{H} 2 \mathrm{~b}$ \\
\hline & Li and Wang (2010) & China & - & $\mathrm{H} 2 \mathrm{~b}$ \\
\hline & Umutlu and Shackleton (2015) & Korea & - & $\mathrm{H} 2 \mathrm{~b}$ \\
\hline & Yang et al. (2017) & Korea & - & $\mathrm{H} 2 \mathrm{~b}$ \\
\hline & Basak and Pavlova (2013) & Theory & + & H1a \\
\hline & Bae et al. (2011) & Korea & + & $\mathrm{H1a}$ \\
\hline \multirow[t]{4}{*}{ Individuals } & Daigler and Wiley (1999) & US & + & $\mathrm{H} 2 \mathrm{a}$ \\
\hline & Cai et al. (2010) & China & + & $\mathrm{H} 2 \mathrm{a}$ \\
\hline & Che (2018) & Norway & - & $\mathrm{H} 1 \mathrm{~b}$ \\
\hline & Bae et al. (2011) & Korea & - & $\mathrm{H} 1 \mathrm{~b}$ \\
\hline \multirow[t]{6}{*}{ Foreign } & Brennan and Cao (1997) & US & + & $\mathrm{H} 1 \mathrm{a}, \mathrm{H} 2 \mathrm{a}$ \\
\hline & Grinblatt and Keloharju (2001) & Finland & + & H1a \\
\hline & Jeon and Moffett (2010) & Korea & + & H1a \\
\hline & Bae et al. (2011) & Korea & + & H1a \\
\hline & Chen et al. (2013) & China & + & $\mathrm{H} 2 \mathrm{a}$ \\
\hline & Che (2018) & Norway & + & $\mathrm{H} 1 \mathrm{a}, \mathrm{H} 2 \mathrm{a}$ \\
\hline
\end{tabular}

